\title{
Biological activities of extracts from Chenopodium ambrosioides Lineu and Kielmeyera neglecta Saddi
}

\author{
Zulane Lima Sousa', Fernando Faustino de Oliveira ${ }^{2}$, Aline Oliveira da Conceição ${ }^{3}$, Luiz Alberto Mattos Silva ${ }^{3}$, \\ Maria Helena Rossi ${ }^{4}$, Juliana da Silva Santos ${ }^{4}$ and João Luciano Andrioli ${ }^{1,3^{*}}$
}

\begin{abstract}
Background: Chenopodium ambrosioides and Kielmeyera neglecta are plants traditionally used in Brazil to treat various infectious diseases. The study of the biological activities of these plants is of great importance for the detection of biologically active compounds.

Methods: Extracts from these plants were extracted with hexane (Hex), dichloromethane (DCM), ethyl acetate (EtOAc) and ethanol (EtOH) and assessed for their antimicrobial properties, bioactivity against Artemia salina Leach and antifungal action on the cell wall of Neurospora crassa.

Results: Extracts from C. ambrosioides (Hex, DCM and EtOH) and K. neglecta (EtOAc and EtOH) showed high bioactivity against $A$. salina $(\mathrm{LD} 50<1000 \mathrm{\mu g} / \mathrm{mL})$, which might be associated with cytotoxic activity against cancer cells. C. ambrosioides Hex and DCM showed specific activity against yeasts, highlighting the activity of hexanic extract against Candida krusei $(\mathrm{MIC}=100 \mu \mathrm{g} / \mathrm{mL})$. By comparing the inhibitory concentration of $50 \%$ growth (IC 50\%) with the growth control, extracts from K. neglecta EtOAc and EtOH have shown activities against multidrug-resistant bacteria (Enterococcus faecalis ATCC 51299 and Staphylococcus aureus ATCC 43300), with IC 50\% of $12.5 \mu \mathrm{g} / \mathrm{mL}$ The assay carried out on $\mathrm{N}$. crassa allowed defining that extracts with antifungal activity do not have action through inhibition of cell wall synthesis.
\end{abstract}

Conclusions: Generally speaking, extracts from C. ambrosioides and K. neglecta showed biological activities that have made the search for bioactive substances in these plants more attractive, illustrating the success of their use in the Brazilian folk medicine.

Keywords: Antimicrobial, Bioactivity, Extract, Chenopodium ambrosioides, Kielmeyera neglecta, Candida

\section{Background}

The observed medical advances over the last years has led to an increase in the survival of immunocompromised people; because this population group is affected by some disease that suppresses the immune system, such as AIDS, or due to intensive use of chemotherapy or immunosuppressive drugs, these people are more susceptible to opportunistic infections like candidiasis, which are considered difficult to treat in these cases [1-3]. In addition to this,

\footnotetext{
* Correspondence: joaoluciano2002@yahoo.com.br

'Programa de Pós-graduação em Biologia e Biotecnologia de

Microrganismos, Universidade Estadual de Santa Cruz, Campus Prof. Soane Nazaré de Andrade, Km 16 - Rodovia Ilhéus/Itabuna, 45662-900 Ilhéus, Brazil ${ }^{3}$ Departamento de Ciências Biológicas, Universidade Estadual de Santa Cruz, Campus Prof. Soane Nazaré de Andrade, Km 16 - Rodovia Ilhéus/ltabuna, 45662-900 Ilhéus, Brazil

Full list of author information is available at the end of the article
}

there is an increase in the number of microorganisms resistant or multiresistant to antibiotics [3-5], such as the methicillin-resistant Staphylococcus aureus (MRSA), which is one of the major bacterial species causing nosocomial infections worldwide [6]. Together, these factors stimulate the search for new drugs that are effective and less toxic to patients $[1,2,7]$. In this context, natural products have been historically and continue to be the focus of researches on antimicrobial drugs [8], the main source of which is to be found in plants [9].

The use of plants in the treatment of infectious diseases is common since ancient times [10], evidencing its great potential in the research of antimicrobial components. This potential can be explained by the large variety and complexity of secondary metabolites synthesized by plants as a result of adaptive and defensive mechanisms against

\section{Biomed Central}

(C) 2012 Sousa et al.; licensee BioMed Central Ltd. This is an Open Access article distributed under the terms of the Creative Commons Attribution License (http://creativecommons.org/licenses/by/2.0), which permits unrestricted use, distribution, and reproduction in any medium, provided the original work is properly cited. 
insects, animals and microorganisms [11]. Hence, plants are regarded as a great laboratory of organic synthesis, as a result of millions of years of adaptation, providing an invaluable source of new molecules for researching antimicrobial activities [12-14].

It is of great interest that experimental studies of new drugs are conducted using ethnopharmacology, i.e., the study of biological activities of plants with medicinal use supported by popular knowledge [15], since this approach has a great potential to find new bioactive substances [16].

Chenopodium ambrosioides Lineu is an herb of the Chenopodiaceae family, indigenous to South America, with broad geographic distribution in Brazil, popularly known as "mastruz" [17-19]; furthermore, this plant is traditionally and widely used as anti-parasitic, anti-inflammatory and antibiotic, which efficacy has been scientifically proven $[18,20,21]$. The essential oil of C. ambrosioides is known to inhibit the growth of yeast species [22], dermatophytes [23] and other filamentous fungi $[23,24]$ and the hexane extract of C. ambrosioides is known to inhibit the growth of filamentous fungi [17]. However, further studies are needed with different microorganisms.

Kielmeyera neglecta Saddi is a plant of the Clusiaceae family, endemical to Southern Bahia, Brazil, and found in the Atlantic Forest [25]; this plant is popularly known as "pau-santo" (holy-wood) [26], term also used to denominate plants of the same genus [27-29], which are used in the Brazilian folk medicine to treat various infectious diseases [4]. Previous studies have demonstrated the existence of antibacterial and antifungal activities of extracts from these plants [2,30], but additional studies are still needed.

Apart from dealing with the assessment of different extracts from C. ambrosioides and $K$. neglecta as for their antibacterial and antifungal properties, this study addresses the bioactivity against Artemia salina Leach and the antifungal effect on the cell wall of Neurospora crassa.

\section{Methods}

\section{Plant material}

Branches containing leaves and seeds of C. ambrosioides were collected in Ilhéus, whereas leaves from $K$. neglecta were collected in Una, both cities in the state of Bahia, Brazil. Data collection was performed in May 2010; the material was identified by the teacher Luiz Alberto Silva Mattos and voucher specimens were deposited at the herbarium of Universidade Estadual de Santa Cruz (HUESC).

\section{Preparation of extracts}

After drying in a ventilated oven at $50^{\circ} \mathrm{C}$, for $5 \mathrm{~h}$, aerial parts of C. ambrosioides (633.3 g) and leaves of $K$. neglecta (1783.0 g) were ground and extracted by exhaustive maceration in sequence with the solvents hexane (Hex), dichloromethane (DCM), ethyl acetate (EtOAc) and ethanol $(\mathrm{EtOH})$; after filtration through filter paper, solvents were removed by a rotary evaporator, under reduced pressure, and temperature below the boiling point of the solvent, thus obtaining extracts Hex (15.2 g), DCM (18.6 g), EtOAc (9.2 g) and EtOH (34.2 g) for C. ambrosioides and Hex (28.3 g), DCM (47.7 g), EtOAc (16.4 g) and EtOH $(35.0 \mathrm{~g})$ for $K$. neglecta. All extracts were kept in glass flasks, at room temperature, until their application. For the preparation of solutions to be used in the bioactivity against Artemia salina, all extracts were solubilized in ethanol so as to attain the desired concentration; regarding the other assays, EtOAc and EtOH extracts were resuspended in dimethyl sulfoxide, whereas Hex and DCM were resuspended in ethanol. The solutions for use in microbial assays were filtered through a $0.22 \mu \mathrm{m}$ pore membrane and maintained refrigerated until use.

\section{Bacteria and fungi}

The microorganisms used in the study were: Enterococcus faecalis ATCC 29212, E. faecalis ATCC 51299, Escherichia coli ATCC 25922, E. coli ATCC 35218, Klebsiella pneumoniae ATCC 700603, Pseudomonas aeruginosa ATCC 27853, S. aureus ATCC 29213, S. aureus ATCC 43300, Candida albicans ATCC 90028, C. albicans ATCC 10231, C. parapsilosis ATCC 90018, C. parapsilosis ATCC 22019, C. krusei ATCC 6258. The $N$. crassa isolate used to assess antifungal effects on the cell wall was kindly granted by Dr. Antonio Carlos Monteiro (UNESP, Jaboticabal, Brazil).

\section{Assay using Artemia salina}

The assessment of bioactivity of extracts was carried out following the methodology described by Meyer et al. [31], with modifications. In order to obtain a nauplii population, crustacean cysts (INVE do Brasil, Fortaleza, Brazil) were incubated in sea water at room temperature, under direct light, for $48 \mathrm{~h}$. The preparation of solutions with different concentrations of extract was performed by diluting the working solution in sea water with $1 \%$ Tween 80 . These solutions were dispensed in 24-well plates to which ten nauplii have been added, and plates were incubated at room temperature, under direct light. After 6 and $24 \mathrm{~h}$, the number of survivors was counted so as to determine the lethal concentration capable of eliminating $50 \%$ of organisms $\left(\mathrm{LC}_{50}\right)$. The final concentrations of the tested extracts ranged between 100 and $2000 \mu \mathrm{g} / \mathrm{mL}$; the concentration of Tween 80 was $0.94 \%$ and that of ethanol was below $1 \%$. Negative and positive controls were simultaneously performed using the same concentrations of the working solvent and $\mathrm{K}_{2} \mathrm{Cr}_{2} \mathrm{O}_{7}(0.33 \mathrm{mM})$, respectively. The assays were performed in triplicate. $\mathrm{LC}_{50}$ was calculated using the probit method (BioStat, 2009), with a 95\% confidence interval. The mortality was corrected using Abbott's formula: $\quad \mathrm{M}_{\mathrm{c}}=\left[\mathrm{M}_{\mathrm{t}}(\%)-\mathrm{M}_{\mathrm{nc}}(\%) / 100-\mathrm{M}_{\mathrm{nc}}(\%)\right] \times 100$, where $M_{c}=$ corrected mortality; $M_{t}=$ mortality of the test; $\mathrm{M}_{\mathrm{nc}}=$ mortality of negative control [32]. 


\section{Antimicrobial activity}

Broth microdilution test was performed in accordance with the norms established by the Clinical and Laboratory Standards Institute (CLSI): M27-A6 [33], for bacteria, and M27-A2 [34], for yeasts.

Bacterial $\left(10^{8} \mathrm{UFC} / \mathrm{mL}\right)$ and yeast cells $\left(10^{6} \mathrm{UFC} / \mathrm{mL}\right)$ were inoculated in Mueller-Hinton broth and RPMI 1640 medium, respectively, in 96-well microdilution plates in the presence of extract at different concentrations, with final inoculum concentrations of $10^{5} \mathrm{UFC} / \mathrm{mL}$ for bacteria, and $10^{3} \mathrm{UFC} / \mathrm{mL}$ for yeasts. After $24 \mathrm{~h}$ of incubation at $35^{\circ} \mathrm{C}$, the minimum inhibitory concentration (MIC) considered the lowest concentration of the extract at which there was no visible growth of organisms - and the inhibitory concentration of $50 \%$ growth (IC 50\%), defined as the lowest concentration of extract that can inhibit $50 \%$ of visible microbial growth have been determined. In cases of complete growth inhibition during the evaluation of antifungal activity, the minimum fungicidal concentration (MFC) defined as the lowest extract concentration that could completely eliminate the microorganism was confirmed by re-inoculation of $20 \mu \mathrm{L}$ of the medium in microdilution culture plates in which there was no visible growth in Sabouraud Dextrose Agar, and incubated for $48 \mathrm{~h}$ at $35^{\circ} \mathrm{C}$. The final concentrations of the tested extracts were $12.5-500 \mu \mathrm{g} / \mathrm{mL}$ for antibacterial activity, and 0.8 $500 \mu \mathrm{g} / \mathrm{mL}$ for antifungal activity. Controls on growth, sterility of the medium, sterility of the extract, as well as negative (at the same concentrations of solvents) and positive controls (chloramphenicol at $50 \mu \mathrm{g} / \mathrm{mL}$ and amphotericin $\mathrm{B}$ at $5 \mu \mathrm{g} / \mathrm{mL}$ ) were simultaneously conducted. All trials were performed in triplicate.

\section{Antifungal action on the cell wall of $N$. crassa}

In the cell wall inhibition assay of $N$. crassa, the agar diffusion method allows macroscopic detection of inhibitors of fungal cell wall [35]. In appropriate medium and conditions and in the presence of cell wall inhibitors, the fungus grows as protoplasm, showing clear inhibition halo and undefined borders [36]. Evaluation of the antifungal action of extracts on the cell wall of $N$. crassa was performed following the methodology proposed by Boeck et al. [35]. N. crassa was grown on Sabouraud Dextrose Agar for 3 days, at room temperature, directly exposed to sunlight, thus producing an orange mycelium and spores; Using a Neubauer chamber, the spore inoculum was prepared and adjusted to $1 \times 10^{6}$ spores $/ \mathrm{mL}$ with a buffer solution containing $0.075 \mathrm{~g} / 100 \mathrm{~mL} \mathrm{~K} \mathrm{HPO}_{4}, 0.10 \mathrm{~g} / 100 \mathrm{~mL} \mathrm{KH}_{2} \mathrm{PO}_{4}$ in a $\mathrm{H}_{2} \mathrm{O}$ 15:85 glycerol solution. Thirty milliliters of the osmotic medium with $0.5 \%$ peptone, $1.0 \%$ yeast extract, $4.0 \%$ sucrose and $1.5 \%$ agar has been autoclaved $\left(121^{\circ} \mathrm{C}\right.$, $15 \mathrm{~min})$. Shortly after, it was cooled to $45^{\circ} \mathrm{C}, 30 \mu \mathrm{L}$ of the spore inoculum were added, and the solution was homogenized and placed in $90 \mathrm{~mm}$ diameter Petri plates; after solidification, $4.8 \mathrm{~mm}$ wells were made and $30 \mu \mathrm{L}$ of solutions from the testing extract were dispensed at a concentration of $500 \mathrm{mg} / \mathrm{mL}$ achieved by diluting the working solution in distilled water. After incubation at room temperature, under direct light for $24 \mathrm{~h}$, it has been macroscopically observed the presence of an inhibition halo. In the presence of cell wall inhibitors, the fungus grows as protoplasm, producing a halo of misty appearance. The solvents used for dilution of the extract have been used as a negative control, whereas ketoconazole $(30 \mu \mathrm{g} / \mathrm{mL})$ has been used as a positive control. The assay consisted of three separate trials.

\section{Results and discussion}

The crustacean $A$. salina is highly sensitive to a variety of compounds [37] and is considered to be a useful screening tool of active substances in bioassay [4,31]; furthermore, it has good correlation with cytotoxicity in human cancer cells $[31,38]$. As shown in Table 1, results indicate high bioactivity $\left(\mathrm{LC}_{50}<1000 \mu \mathrm{g} / \mathrm{mL}\right)$ for extracts from $\mathrm{K}$. neglecta EtOAc and $\mathrm{EtOH}$, and C. ambrosioides DCM and EtOH were considered as active $[31,39,40]$. As compared with the other tested extracts, C. ambrosioides Hex showed very high mortality rate (Figure 1 ) and thereby made it statistically impossible to calculate the $\mathrm{LC}_{50}$, but was considered to be an active extract. Bioactivity in $6 \mathrm{~h}$ was only high for C. ambrosioides Hex, reinforcing the possibility for this extract to contain bioactive compounds.

Antimicrobial activity was analyzed based on the results of MIC and IC 50\% displayed in Table 2. It was possible to determine the minimal inhibitory concentration only for the extract from C. ambrosioides Hex $(100 \mu \mathrm{g} / \mathrm{mL})$ against C. krusei, which has clearly shown complete inhibition; when examining the reading for $50 \% \mathrm{CI}$, the concentration was $3.1 \mu \mathrm{g} / \mathrm{mL}$. For some antifungals, the reading of MIC is based on $50 \%$ of growth inhibition [34]; then, the

\section{Table 1 Bioactivity of extracts of Chenopodium ambrosioides and Kielmeyera neglecta against Artemia salina}

\begin{tabular}{llcc}
\hline & & \multicolumn{2}{c}{$\mathbf{L C}_{50}(\boldsymbol{\mu g} \mathbf{g} \mathbf{m L})$} \\
\cline { 3 - 4 } Species & Extract & $\mathbf{6} \mathbf{~ h}$ & $\mathbf{2 4} \mathbf{~ h}$ \\
\hline K. neglecta & Hex & 2699.8 & 1050.8 \\
& DCM & $-*$ & 1379.2 \\
& EtOAC & 1324.8 & 780.8 \\
C. ambrosioides & EtOH & 2154.5 & 977.7 \\
& Hex & $-\#$ & $-\#$ \\
& DCM & 1371.2 & 359.9 \\
& EtOAC & $-*$ & 1444.4 \\
& EtOH & 1059.0 & 356.6 \\
\hline
\end{tabular}

Hex, hexane; DCM, dichloromethane; EtOAc, ethyl acetate; EtOH, ethanol. * No

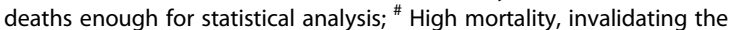
statistical test. 


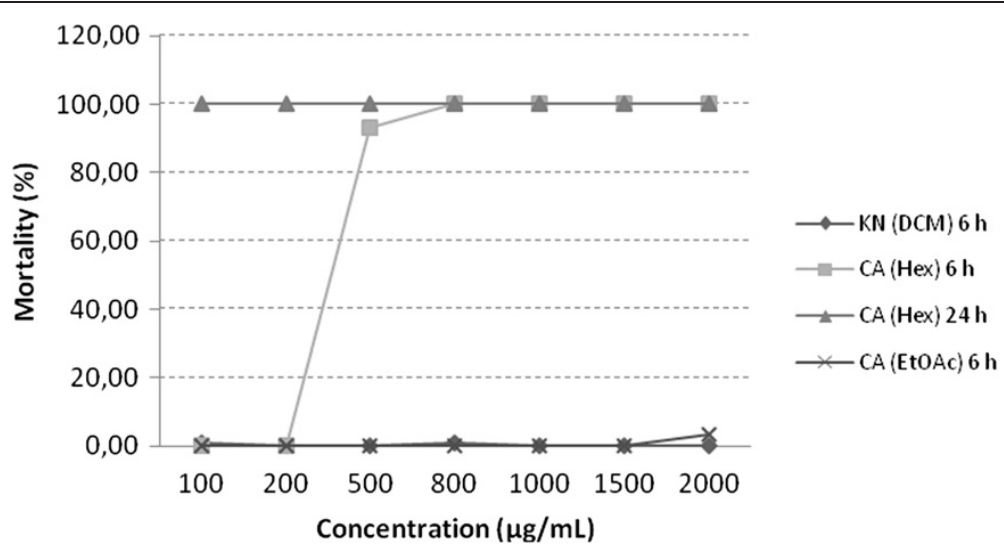

Figure 1 Mortality of Artemia salina to extracts of $K$. neglecta (KN) and C. ambrosioides (CA); Hex, hexane; DCM, dichloromethane; EtOAc, ethyl acetate.

reading of IC 50\% should be considered when screening plants with antimicrobial activity. An antimicrobial activity can be considered as positive when the action of the extract occurs at concentrations lower than $100 \mu \mathrm{g} / \mathrm{mL}$ [10]; hence, when considering the reading of IC 50\%, five extracts are regarded as very important against at least one organism; on the other hand, when analyzing MIC, only C. ambrosioides Hex was considered significant. Despite the MIC and IC $50 \%$ at $100 \mu \mathrm{g} / \mathrm{mL}$ for C. ambrosioides Hex and DCM, respectively, the genuine inhibitory concentration is between that concentration read in the test and the one next lower tested concentration [33]; then, its true $50 \% \mathrm{MIC} / \mathrm{IC}$ is lower than $100 \mu \mathrm{g} / \mathrm{mL}$. When analyzing the reading of IC $50 \%$, extracts from C. ambrosioides have not shown antibacterial activity, but antifungal activity with Hex and DCM. In turn,
K. neglecta showed antibacterial activity against Gram positive bacteria, as well as antifungal activity against nonalbicans Candida species (Hex, EtOAc, EtOH). It is noteworthy that extracts from $K$. neglecta EtOAc and EtOH had the same IC 50\% when tested with E. faecalis ATCC 51299 and S. aureus ATCC 43300 multidrug-resistant bacteria.

As the extract from C. ambrosioides Hex was the only one with complete inhibition of visible growth, the evaluation of MFC was only performed for this extract. With a final concentration of $200 \mu \mathrm{g} / \mathrm{mL}$, this extract was considered to exert a fungicidal effect against $C$. krusei. This yeast is regarded as intrinsically resistant to fluconazole and resistant to other antifungals such as itraconazole and flucytosine [41]; this is an interesting result because, as there is an activity targeted against C. krusei, the compounds

Table 2 Antimicrobial activity of extracts of $K$. neglecta and C. ambrosioides

\begin{tabular}{|c|c|c|c|c|c|c|c|c|}
\hline \multirow{3}{*}{ Microorganisms } & \multicolumn{8}{|c|}{$\mathrm{MIC} / \mathrm{IC} 50 \%(\mu \mathrm{g} / \mathrm{mL})$} \\
\hline & \multicolumn{4}{|c|}{ K. neglecta } & \multicolumn{4}{|c|}{ C. ambrosioides } \\
\hline & Hex & DCM & EtOAc & EtOH & Hex & DCM & EtOAc & EtOH \\
\hline E. faecalis ATCC 29212 & $-1-$ & $-/-$ & $-1-$ & $-/ 12.5$ & $-1-$ & $-/-$ & $-1-$ & $-/-$ \\
\hline E. faecalis ATCC 51299 & $-1-$ & $-1-$ & $-1-$ & $-/ 12.5$ & $-1-$ & $-1-$ & $-1-$ & $-/-$ \\
\hline E. coli ATCC 25922 & $-1-$ & $-/-$ & $-/-$ & $-/-$ & $-1-$ & $-/-$ & $-/-$ & $-/-$ \\
\hline E. coli ATCC 35218 & $-/-$ & $-/-$ & $-/-$ & $-/-$ & $-1-$ & $-/-$ & $-/-$ & $-/-$ \\
\hline K. pneumoniae ATCC 700603 & $-1-$ & $-1-$ & $-1-$ & $-/-$ & $-1-$ & $-1-$ & $-1-$ & $-/-$ \\
\hline P. aeruginosa ATCC 27853 & $-1-$ & $-1-$ & $-1-$ & $-1-$ & $-1-$ & $-1-$ & $-1-$ & $-1-$ \\
\hline S. aureus ATCC 29213 & $-/ 12.5$ & $-/-$ & $-/ 12.5$ & $-/ 12.5$ & $-1-$ & $-/-$ & $-1-$ & $-1-$ \\
\hline S. aureus ATCC 43300 & $-1-$ & $-1-$ & $-/ 12.5$ & $-/ 12.5$ & $-1-$ & $-1-$ & $-1-$ & $-/-$ \\
\hline C. albicans ATCC 90028 & $-1-$ & $-/-$ & $-/-$ & $-/-$ & $-1-$ & $-/ 300$ & $-1-$ & $-/-$ \\
\hline C. albicans ATCC 10231 & $-1-$ & $-1-$ & $-1-$ & $-1-$ & $-/ 50$ & $-/ 300$ & $-1-$ & $-1-$ \\
\hline C. parapsilosis ATCC 90018 & $-/-$ & $-/-$ & $-/ 300$ & $-/-$ & $-/ 50$ & $-/-$ & $-/-$ & $-/-$ \\
\hline C. parapsilosis ATCC 22019 & $-/-$ & $-/-$ & $-/ 300$ & $-/-$ & $-/ 50$ & $-/ 300$ & $-/-$ & $-/-$ \\
\hline C. krusei ATCC 6258 & $-/ 500$ & $-/-$ & $-/ 200$ & $-/ 200$ & $100 / 3.1$ & $-/ 100$ & $-1-$ & $-/-$ \\
\hline
\end{tabular}


present in this extract can be used in the formulation of drugs for an specific treatment of candidiasis caused by this species, which has increased over the last years [41,42]. The different concentrations of MIC $(100 \mu \mathrm{g} / \mathrm{mL})$ and MFC can be explained by the reading of visible growth, without automation, as suggested by the CLSI [34]; that may result in some variations in results.

The extracts that showed antimicrobial activity against the tested yeasts, K.neglecta (Hex, EtOAc and $\mathrm{EtOH}$ ) and
C. ambrosioides (Hex and DCM) were evaluated as for the action on the cell wall of $N$. crassa, but showed no inhibition halo at the tested concentration, either antifungal action related to cell wall inhibition. Despite no action has been detected on cell wall using this method, it is possible that antifungal action occurs through another mechanism.

A preliminary chemical study of extracts of roots and branches from $K$. neglecta resulted in the isolation of 24 substances which identification and determination of

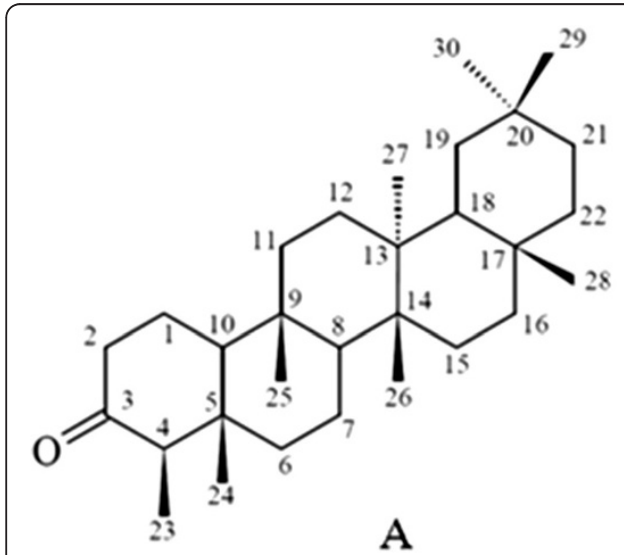

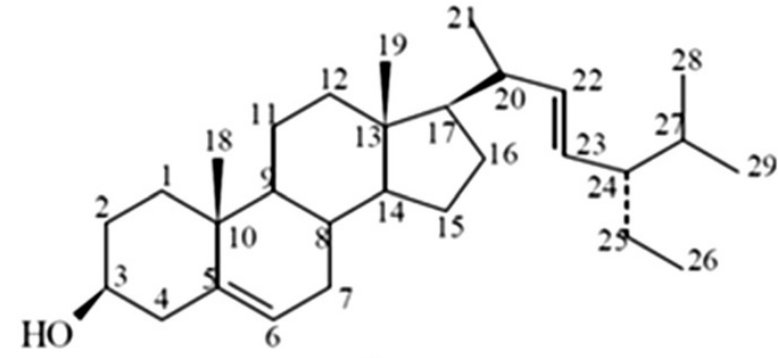

C<smiles>CC1(C)C=Cc2cc(O)c3c(=O)c4cc5c(c(O)c4oc3c2O1)OC(C)(C)C5(C)C</smiles>

E

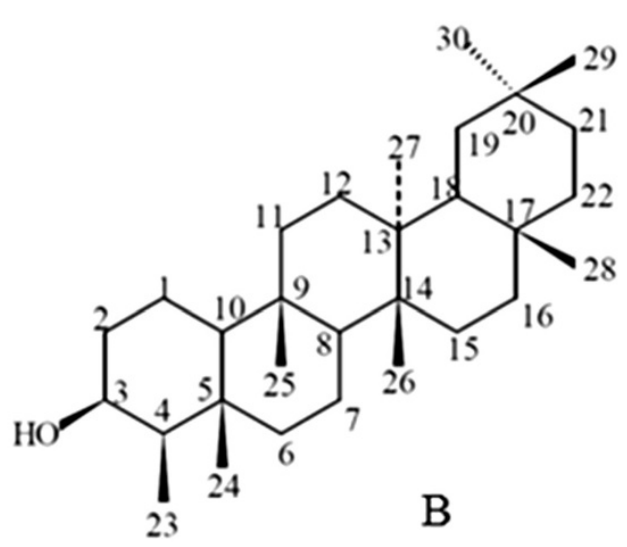<smiles>CCC(CCC(C)C1CCC2C1CCC1CC=C3C=C(O)CCC3[C@]12C)C(C)C</smiles>

$\mathrm{D}$<smiles>O=c1c2cc(O)ccc2oc2cccc(O)c12</smiles>

$\mathrm{F}$

Figure 2 Chemical structures identified from $K$. neglecta: friedelan-3-one (A), friedelan-3- $\beta$-ol (B), $\beta$-sitosterol (C), stigmasterol (D), 1,8dihydroxy-6,6-dimethylpyrano(2,3;5,6)-4/,4/,5/-trimethyldihydrofuran( $2 /, 3 / ; 2,3)$ xanthone (E), 1,7-dihydroxyxanthone (F). With permission of the author. (Oliveira, unpublished results). 
structures by spectrometric methods (UV, IR, ${ }^{1} \mathrm{H}$ NMR, ${ }^{13} \mathrm{C}$ NMR, NOESY) and comparison with data from the literature were done. Isolated substances were the triterpenes friedelan-3-one (friedelin) (Figure 2A) and friedelan-3- $\beta$-ol (friedelinol) (Figure 2B); the steroids $\beta$-sitosterol (Figure 2C) and stigmasterol (Figure 2D); and the xanthones 1,8-dihydroxy-6,6-dimethylpyrano(2,3;5,6)-4/,4/,5/-trimethyldihydrofuran $(2 /, 3 / ; 2,3)$ xanthone (Figure 2E) and 1,7-dihydroxyxanthone (Figure 2F) [43]. The analysis of biological activities with the isolated compounds was not performed, but it might be possible that the xanthones present in $K$. neglecta are synergistically responsible for the antifungal activity presented in this study, as some xanthones isolated from $K$. coriacea have proven to have antifungal activity against Cladosporium cucumerinum and C. albicans, whereof some have shown a fungicidal effect against the latter [44]. Antimicrobial activity against Candida species can also be explained by the compound friedelin, which has been shown to have activity against C. albicans, C. krusei and C. glabrata [45]. In addition, friedelin has shown to have microbicidal activity against E. faecalis [45] and $S$. aureus [46], whereas friedelinol has shown to have microbicidal activity against $S$. aureus [46].

A preliminary qualitative chemical analysis of extracts of C. ambrosioides obtained in this study, conducted according to Matos [47], revealed the presence of phenolic compounds, tannins, flavonoids and steroids for the EtOH extract, phenolic compounds, tannins and flavonoids for the EtOAc extract and flavonoids and steroids for the DCM extract. Ascaridol has been the major antifungal compound identified in extracts of $C$. ambrosioides, with activity against Aspergillus flavus, A. glaucus, A. ochraceous, A. niger, Fusarium semitectum, $F$. oxysporum, Colletotrichum musae and C. gloeosporioides. [17,24], being probably this compound the responsible for the activity of $C$. ambrosioides against Candida species in ours study.

\section{Conclusion}

This study has demonstrated that these two plants - K.neglecta and C. ambrosioides - used in the Brazilian folk medicine are a potential source of substances with biological activities. By showing bioactivity against $A$. salina, $K$. neglecta EtOAc and EtOH and C. ambrosioides Hex, DCM and $\mathrm{EtOH}$ may be considered extracts that potentially contain substances with cytotoxic activity against cancer cells. The IC 50\% determination has been proved to be useful in the screening of extracts with antimicrobial activity and should be considered as an important tool in researches involving natural products. Extracts from $K$. neglecta EtOAc and EtOH showed activity against multidrug-resistant bacteria, which are of great concern in medicine nowadays; in turn, C. ambrosioides Hex and DCM showed specific activity against yeasts. These results showed here confirm once more the $K$. neglecta and C. ambrosioides extracts potential biological activities.

\section{Competing interests}

The authors declare that they have no competing interests.

\section{Authors' contributions}

ZLS performed the extraction, the laboratory assays and drafted the manuscript. FFO participated in the design of the chemical study. AOC helped to draft the manuscript. LAMS performed the collection and identification of plant material. MHR and JSS conducted preliminary chemical analysis. JLA participated in the design and coordination of the study. All authors read and approved the final manuscript.

\section{Acknowledgments}

We are thankful to the Universidade Estadual de Santa Cruz for providing physical and financial support for the development of this study; and to the Coordination for the Improvement of Higher Education Personnel

(Coordenação de Aperfeiçoamento de Pessoal de Nível Superior - CAPES) for granting the scholarship to Zulane Lima Sousa.

\section{Author details}

${ }^{1}$ Programa de Pós-graduação em Biologia e Biotecnologia de Microrganismos, Universidade Estadual de Santa Cruz, Campus Prof. Soane Nazaré de Andrade, Km 16 - Rodovia Ilhéus/Itabuna, 45662-900 Ilhéus, Brazil. ${ }^{2}$ Departamento de Ciências Exatas e Tecnológicas, Universidade Estadual de Santa Cruz, Campus Prof. Soane Nazaré de Andrade, Km 16 - Rodovia Ilhéus/ Itabuna, 45662-900 Ilhéus, Brazil. ³Departamento de Ciências Biológicas, Universidade Estadual de Santa Cruz, Campus Prof. Soane Nazaré de Andrade, Km 16 - Rodovia Ilhéus/Itabuna, 45662-900 Ilhéus, Brazil. ${ }^{4}$ Instituto Biológico, Centro de Sanidade Animal, Av. Cons. Rodrigues Alves, 1252, 04014-002 São Paulo, Brazil.

Received: 22 May 2012 Accepted: 22 July 2012

Published: 28 July 2012

\section{References}

1. Fenner R, Sortino M, Kuze Rates SM, Dall'Agnol R, Ferraz A, Bernardi AP, Albring D, Nör C, von Poser G, Schapoval E, Zacchino S: Antifungal activity of some Brazilian Hypericum species. Phytomedicine 2005, 12:236-240.

2. Silva FM, de Paula JE, Espindola LS: Evaluation of the antifungal potencial of Brazilian Cerrado medicinal plants. Mycoses 2009, 52:511-517.

3. Brandão GC, Kroon EG, Duarte MGR, Braga CB, de Souza Filho JD, Oliveira $A B$ : Antimicrobial, antiviral and cytotoxic activity of extracts and constituents from Polygonum spectabile Mart. Phytomedicine 2010, 17:926-929.

4. Alves TMA, Silva AF, Brandão M, Grandi TSM, Smânia EFA, Smânia Júnior A, Zani CL: Biological screening of Brazilian medicinal plants. Mem Inst Oswaldo Cruz 2000, 95:367-373.

5. Salvat A, Antonacci L, Fortunato RH, Suarez EY, Godoy HM: Antimicrobial activity in methanolic extracts of several plant species from northern Argentina. Phytomedicine 2004, 11:230-234.

6. Yasunaka K, Abe F, Nagayama A, Okabe H, Lozada-Pérez L, López-Villafranco E, Muñiz EE, Aguilar A, Reyes-Chilpa R: Antibacterial activity of crude extracts from Mexican medicinal plants and purified coumarins and xanthones. J Ethnopharmacol 2005, 97:293-299.

7. Valgas C, Souza SM, Smânia EFA, Smânia A Jr: Screening methods to determine antibacterial activity of natural products. Braz J Microbiol 2007, 38:369-380.

8. Li JWH, Vederas J: Drug Discovery and natural products: end of an era or an endless frontier? Science 2009, 325:161-165.

9. Harvey AL: Natural products in drug discovery. Drug Discov Today 2008 , 13:894-901.

10. Ríos $J$, Recio MC: Medicinal plants and antimicrobial activity. $J$ Ethnopharmacol 2005, 100:80-84.

11. Cowan MM: Plant products as antimicrobial agents. Clin Microbiol Rev 1999, 12:564-582.

12. Montanari CA, Bolzani VS: Planejamento racional de fármacos baseado em produtos naturais. Quim Nova 2001, 24:105-111.

13. Gurib-Fakim A: Medicinal plants: traditions of yesterday and drugs of tomorrow. Mol Aspects Med 2006, 27:1-93. 
14. Harvey AL: Natural products as a screening resource. Curr Opin Chem Biol 2007, 11:480-484.

15. Rehecho S, Uriarte-Pueyo I, Calvo J, Vivas LA, Calvo MI: Ethnopharmacological survey of medicinal plants in Nor-Yauyos, a part of the Landscape Reserve Nor-Yauyos-Cochas, Peru. J Ethnopharmacol 2011, 133:75-85.

16. Maciel MAM, Pinto AC, Veiga VF Jr, Grynberg NF, Echevarria A: Plantas medicinais: a necessidade de estudos multidisciplinares. Quim Nova 2002, 25:429-438

17. Jardim CM, Jham GN, Dhingra O, Freire MM: Chemical composition and antifungal activity of the hexane extract of the Brazilian Chenopodium ambrosioides L. J Braz Chem Soc 2010, 21:1814-1818.

18. Pereira WS, Ribeiro BP, Sousa AIP, Serra ICPB, Mattar NS, Fortes TS, Reis AS, Silva LA, Barroqueiro ESB: Evaluation of the subchronic toxicity of oral treatment with Chenopodium ambrosioides in mice. J Ethnopharmacol 2010, 127:602-605.

19. Senna L: Chenopodium. In Lista de Espécies da Flora do Brasil. Brasil: Jardim Botânico do Rio de Janeiro; 2010.

20. de Souza CD, Felfili JM: Uso de plantas medicinais na região de Alto Paraíso de Goiás, GO, Brasil. Acta Botanica Brasilica 2006, 20:135-142.

21. Brito MVH, Carvalho DS, Albuquerque AMM: Efeito do extrato de mastruz em culturas de Staphylococcus aureus e Escherichia coli. Revista Paraense de Medicina 2007, 21:21-25.

22. Chekem MSG, Lunga PK, Tamakou JDD, Kuiate JR, Tane P, Vilarem G, Cerny M: Antifungal properties of Chenopodium ambrosioides essential oil against Candida species. Pharmaceuticals 2010, 3:2900-2909.

23. Prassad CS, Shukla R, Kumar A, Dubey NK: In vitro and in vivo antifungal activity of essential oils of Cymbopogon martini and Chenopodium ambrosioides and their synergism against dermatophytes. Mycoses 2008 53:123-129.

24. Jardim CM, Jham GN, Dhingra OD, Freire MM: Composition and antifungal activity of the essential oil of the Brazilian Chenopodium ambrosioides L. J Chem Ecol 2008, 34:1213-1218.

25. Bittrich V: Clusiaceae. In Lista de Espécies da Flora do Brasil. Brasil: Jardim Botânico do Rio de Janeiro; 2010.

26. Ministério do Meio Ambiente: Revisão do Zoneamento Ecológico-Econômico: APA Costa de Itacaré-Serra Grande. Brasil: Instituto de Estudos SócioAmbientais do Sul da Bahia; 2004

27. Pinheiro L, Cortez DAG, Vidotti GJ, Young MCM, Ferreira AG: Estudo fitoquímico e avaliação da atividade moluscicida da Kielmeyera variabilis Mart (Clusiaceae). Quim Nova 2003, 26:157-160.

28. Zagoto JN, Bracht A, Pagadigorria CLS, Ishii-Iwamoto EL, Cortez DA, Yamamoto NS: Effects of the Kielmeyera coriacea extract on energy metabolismo in the rat liver. J Ethnopharmacol 2006, 105:47-54.

29. LdeCR S, Correa RS: Sobrevivência e crescimento de seis espécies arbóreas submetidas a quatro tratamentos em área minerada no cerrado. Rev Árvore 2008, 32:731-740.

30. de Toledo CEM, Britta EA, Ceole LF, Silva ER, deMello JCP, Dias Filho BP, Nakamura CV, Ueda-Nakamura T: Antimicrobial and cytotoxic activities of medicinal plants of the Brazilian cerrado, using Brazilian cachaça as extractor liquid. J Ethnopharmacol 2011, 133:420-425.

31. Meyer BN, Ferrigni NR, Putnam JE, Jacobsen LB, Nichols DE, McLaughlin الL: Brine shrimp: a convenient general bioassay for active plant constituents. Planta Med 1982, 45:31-34.

32. David JP, da Silva EF, deMoura DL, Guedes MLS, Assunção RJ, David JM: Lignanas e triterpenos do extrato citotóxico de Eriope blanchetii. Quim Nova 2001, 24:730-733.

33. National Committee for Clinical Laboratory Standards (NCCLS): Methods for Dilution Antimicrobial Susceptibility Tests for Bacteria That Grow Aerobically. Wayne, PA, USA: Approved Standard M7-A6, NCCLS; 2003

34. National Committee for Clinical Laboratory Standards (NCCLS): Reference method for broth dilution antifungal susceptibility testing of yeasts. Wayne, PA, USA: Approved Standard M27-A2. NCCLS; 2002

35. Boeck P, Leal PC, Yunes RA, Cechinel Filho V, López S, Sortino M, Escalante A, Furlán RLE, Zacchino S: Antifungal activity and studies on mode of action of novel xanthoxyline-derived chalcones. Arch Pharm 2005, 338:87-95.

36. Selitrennikoff CP: Use of a temperature-sensitive, protoplast-forming Neurospora crassa strain for the detection of antifungal antibiotics. Antimicrob Agents Chemother 1983, 23:757-765.
37. Michael AS, Thompson CG, Abramovitz M: Artemia salina as a test organism for bioassay. Science 1956, 123:464.

38. Carballo JL, Hernández-Inda ZL, Pérez P, García-Grávalos MD: A comparison between two brine shrimp assays to detect in vitro cytotoxicity in marine natural products. BMC Biotechnol 2002, 2:17

39. Nunes XP, Mesquita RF, Silva DA, Lira DP, Costa VCO, Silva MVB, Xavier AL, Diniz FFM, Agra MF: Constituintes químicos, avaliação das atividades citotóxica e antioxidante de Mimosa paraibana Barneby (Mimosaceae). Rev Bras Farmacogn 2008, 18:718-723.

40. Barbosa TP, Junior CGL, Silva FPL, Lopes HM, Figueiredo LRF, Sousa SCO, Batista GN, daSilva TG, Silva TMS, deOliveira MR, Vasconcellos MLAA: Improved synthesis of seven aromatic Baylis-Hillman adducts (BHA): Evaluation against Artemia salina Leach. and Leishmania chagasi. Eur J Med Chem 2009, 44:1726-1730.

41. Rex JH, Walsh TJ, Sobel JD, Filler SG, Pappas PG, Dismukes WE, Edwards JE: Practice guidelines for the treatment of candidiasis. J Infect Dis 2000, 30:662-678.

42. Andrioli JL, Oliveira GSA, Barreto CS, Sousa ZL, Oliveira MCH, Carzola IM, Fontana R: Frequência de leveduras em fluido vaginal de mulheres com e sem suspeita clínica de candidíase vulvovaginal. Rev Bras Ginecol Obstet 2009, 31:300-304.

43. Oliveira FF: Estudo fitoquímico e biológico de espécies do gênero Kielmeyera (Guttiferae) da região Sul da Bahia. In Relatório final PROPP.: Unpublished results; 2003:1-32.

44. Cortez DAG, Young MCM, Marston A, Wolfender JL, Hostettmann K: Xanthones, triterpenes and a biphenyl from Kielmeyera coriacea. Phytochemistry 1998, 47:1367-1374.

45. Kuete $\mathrm{V}$, Komguem J, Penlap Beng V, Meli AL, Tangmouo TG, Etoa F-X Lontsi D: Antimicrobial components of the methanolic extract from the stem bark of Garcinia smeathmannii Oliver (Clusiaceae). S Afr J Bot 2007, 73:347-354.

46. JdeD T, Tala MF, Wabo HK, Kuiate JR, Tane P: Antimicrobial activities of methanol extract and compounds from stem bark of Vismia rubescens. J Ethnopharmacol 2009, 124:571-575.

47. Matos FJA: Introdução a fitoquímica experimental. Fortaleza: Edições UFC 1997

\section{doi:10.1186/1476-0711-11-20}

Cite this article as: Sousa et al: Biological activities of extracts from Chenopodium ambrosioides Lineu and Kielmeyera neglecta Saddi. Annals of Clinical Microbiology and Antimicrobials 2012 11:20.

\section{Submit your next manuscript to BioMed Central and take full advantage of:}

- Convenient online submission

- Thorough peer review

- No space constraints or color figure charges

- Immediate publication on acceptance

- Inclusion in PubMed, CAS, Scopus and Google Scholar

- Research which is freely available for redistribution 